\title{
Interaction of ionic liquids with human serum albumin in the view of bioconcentration: a preliminary study
}

\author{
Dorota Kowalska $^{1} \oplus \cdot$ Stefan Stolte ${ }^{2} \cdot$ Dariusz Wyrzykowski $^{1} \cdot$ Piotr Stepnowski ${ }^{1} \cdot$ Joanna Dołżonek $^{1,3}$
}

Received: 13 September 2021 / Accepted: 12 December 2021 / Published online: 5 January 2022

(c) The Author(s) 2022

\begin{abstract}
Bioaccumulation potential is critical in PBT and risk assessment of chemicals. However, for ionic liquids (ILs), this aspect remains neglected. It is especially important to fill this gap, because for this group of compounds, existing data confirm their risk of being environmentally persistent and toxicity. Moreover, considering preliminary reports on the interactions of ILs with lipids, it may be assumed that ILs have a higher potential for bioaccumulation than indicated by previous estimations built upon octanol-water partition coefficients. Moreover, the bioconcentration of ionizable chemical compounds may also be strongly related to plasma protein contents. Therefore, in this work, the affinity of a set of imidazolium cations and organic anions, and their combination to human serum albumin (HSA) was determined. The obtained results reveal that both cations and anions can be strongly bound to HSA, and blood proteins might play an important role in overall bioaccumulation. Furthermore, it was observed that HSA binding properties towards IL cations depend on the hydrophobicity of cations. The obtained data also provide indication that cation-anion interaction may affect ILs ions affinity to HSA.
\end{abstract}

Keywords Protein binding $\cdot$ Bioaccumulation $\cdot$ Bioconcentration $\cdot$ Ionic liquids $\cdot$ Human serum albumin

\section{Introduction}

The accumulation of chemicals in biota is of major concern for environmental hazard and risk assessment. For this reason, bioaccumulation assessment is a part of international efforts to identify and control chemicals of environmental concern. The European regulation on the Registration, Evaluation, Authorisation and restriction of Chemicals (REACH), for all the compounds which are produced or imported in the amount of more than 10 tonnes requires that chemicals have to be screened and evaluated for their

Dorota Kowalska

dorota.kowalska@phdstud.ug.edu.pl

1 Department of Environmental Analysis, Faculty of Chemistry, University of Gdańsk, Wita Stwosza 63, 80-308 Gdańsk, Poland

2 Department of Hydrosciences, Faculty of Environmental Sciences, Institute of Water Chemistry, Technische Universität Dresden, Bergstrasse 66, 01069 Dresden, Germany

3 Faculty 4, Center for Environmental Research and Sustainable Technology (UFT), University of Bremen, Leobener Strasse, 28359 Bremen, Germany overall Persistence (P), Bioaccumulation (B) and Toxicity (T)—PBT behaviour (Reach 2006). Although using aquatic species (e.g. OECD TG 305) is the most reliable approach because the results obtained in such tests can be directly compared with the B criterion (Gramatica et al. 2015), due to several concerns, e.g. cost, time and ethical issues, in vitro experiments should be supplanting in vivo tests in bioconcentration assessment.

Generally, membrane and storage lipids have been considered as underlying compartments in the bioaccumulation of organic chemicals (Geisler et al. 2012; Endo et al. 2011). In the assessment of bioaccumulation potential by using octanol-water partition coefficients $\left(\log \mathrm{K}_{\mathrm{OW}}\right)$, the assumption held is that the bioaccumulation of substances is determined mainly by the partitioning between lipid and aqueous phases (Mackay et al. 1982, Meylan et al. 1996). However, it has been already demonstrated that in case of permanently charged and ionogenic compounds, such models are not reliable, because they do not take into account the ion-macromolecule interactions of charged compounds with charged phospholipids (Klamt et al. 2008).

Moreover, the bioconcentration/bioaccumulation potential of chemicals is not only defined by lipid partitioning. Knowledge regarding the partitioning of these compounds to 
proteins is equally important, because it may be an essential sorption phase for this group of compounds (Armitage et al. 2017). In addition, it has been shown that some chemicals (e.g. PFAS) deviate from classical bioaccumulation behaviour, and their accumulating potential within organisms arises from interaction with a number of proteins ( $\mathrm{Ng}$ et al. 2013; Lu et al. 2021).

Although almost half of the 143,000 preregistered compounds in REACH are ionic chemicals, knowledge of their potential for bioconcentration/bioaccumulation is very limited (Franco et al. 2010). Ionic liquids (ILs) have gained much attention among scientists and industry due to their unique properties. Furthermore, due to the fact that ILs are purely ionic compounds, there is the possibility to design an enormous number of cation and anion combinations with different, specific properties. Although they have been hailed as "green solvents" not long ago, significant drawbacks, related mainly to their toxicity and persistence, have already been noticed (Samori et al. 2007; Steudte et al. 2014; Steudte et al. 2012; Stolte et al. 2008; Jeremias et al. 2021; Yue et al. 2021; Mena et al. 2020; Khan et al. 2021). However, data on their potential for accumulation in living organisms are still limited (Kowalska et al. 2021).

Taking into consideration the in vitro studies conducted so far on the bioconcentration potential of ILs, partitioning experiments using phosphatidylocholine have been carried out. The study revealed that ILs may bind to the phospholipid membrane to a great extent (much greater than assumed before on the basis of the $\log$ Kow) and hence can have a potential for bioaccumulation (Dołżonek et al. 2017). Therefore, as a complementary study, it is necessary to assess their interaction with proteins so as to obtain more data for true bioconcentration estimations. For this reason, the aim of this study was to evaluate the affinity of selected cations and anions of ILs (Table 1) to proteins by using the ultrafiltration (UF) technique.

Human serum albumin (HSA) is the main component of blood plasma synthesized in the liver. It reaches a blood concentration of about $0.6 \mathrm{mM}$ (Artali et al. 2005). The modular structural organization of HSA provides a variety of ligand binding sites. For this reason, HSA is the best known for its extraordinary ligand binding capacity. Research on pharmaceuticals and endogenous chemicals has shown that this protein has binding potential towards a broad spectrum of chemicals, especially hydrophobic anions of medium size. Moreover, albumin is responsible, to a great extent, for the distribution of chemicals after they enter the organism (Fanali et al. 2012). Therefore, HSA was chosen as the model protein in our research.

Due to the fact that the structure of long-chain imidazolium ionic liquids is similar to typical surfactants, and they possess surface-active properties and can form micelles in an aqueous solution (Euczak et al. 2008). ILs in a water solution exhibit surface activity, and their micellization process is dependent on the length of the alkyl chain. This is easier for more hydrophobic compounds (Cornellas et al. 2011; Jungnickel et al. 2008; Dong et al. 2008). It has also been shown that the presence of inorganic or organic electrolytes promotes micelle formation in ILs (Dong et al. 2008; Jiao et al. 2013). In addition, the formation of aggregates can potentially have an influence on the binding of ILs to protein. Therefore, we additionally determined the critical micelle concentration for selected ILs in a phosphate saline buffer (PBS), using two techniques: ITC and conductometry. The available procedures have been refined in order to measure the CMC values for ILs in PBS.

\section{Materials and methods}

\section{Chemicals}

Human serum albumin (in the form of lyophilized powder with purity $\geq 97 \%$ ) and benzalkonium chloride were purchased from Sigma-Aldrich (Darmstadt, Germany). Acetonitrile of HPLC grade, potassium dihydrogen phosphate $\left(\mathrm{KH}_{2} \mathrm{PO}_{4}, \geq 99.5 \%\right)$, disodium hydrogen phosphate dihydrate $\left(\mathrm{Na}_{2} \mathrm{HPO}_{4} \cdot 2 \mathrm{H}_{2} \mathrm{O},>99 \%\right)$ and potassium chloride $(\mathrm{KCl},>99 \%)$ were obtained from POCH (Poland). Sodium chloride $(\mathrm{NaCl}>99 \%)$ was acquired from STANLAB (Poland). Orthophosphoric acid $\left(\mathrm{H}_{3} \mathrm{PO}_{4},>99.9 \%\right)$ was procured from CHEMPUR (Poland). 1-decyl-3-methylimidazolium chloride ([IM1-10]Cl, $\geq 95.5 \%$ ), 1-octyl3-methylimidazolium chloride $([\mathrm{C}(8) \mathrm{mim}] \mathrm{Cl}, \geq 97 \%)$, potassium tetracyanoborate $\left(\mathrm{K}\left[\mathrm{B}(\mathrm{CN})_{4}\right],>98 \%\right)$ and lithium bis(trifluoromethylsulfonyl)imide $\mathrm{Li}\left[\left(\mathrm{CF}_{3} \mathrm{SO}_{2}\right)_{2} \mathrm{~N}, 99.95 \%\right]$ were secured from Merck KGaA (Germany). 1-hexyl3-methylimidazolium chloride $([\mathrm{C}(6) \mathrm{mim}] \mathrm{Cl},>98 \%)$ and 1-butyl-3-methylimidazolium chloride ([C(4)mim]Cl, 96\%) were purchased from Iolitec GmbH (Germany). 1-dodecyl3-methylimidazolium sulphate $\left([\mathrm{C}(12) \mathrm{mim}] \mathrm{HSO}_{4}\right)$ and 1-dodecyl-3-methylimidazolium chloride $([\mathrm{C}(12) \mathrm{mim}] \mathrm{Cl})$ were synthesized at the Center for Environmental Research and Sustainable Technology (UFT) of the University of Bremen according to a procedure presented elsewhere (Nowicki et al. 2016).

\section{Materials}

Ultrafiltration VIVASPIN 500 tubes were acquired from Sartorius Stedim Biotech (Germany).

\section{Instrumental analysis}

All cations were analysed by means of an HPLC - DAD system: Shimadzu Nexera XR. A Multhospher® 100 RP18 
Table 1 Names and structures of studied ILs

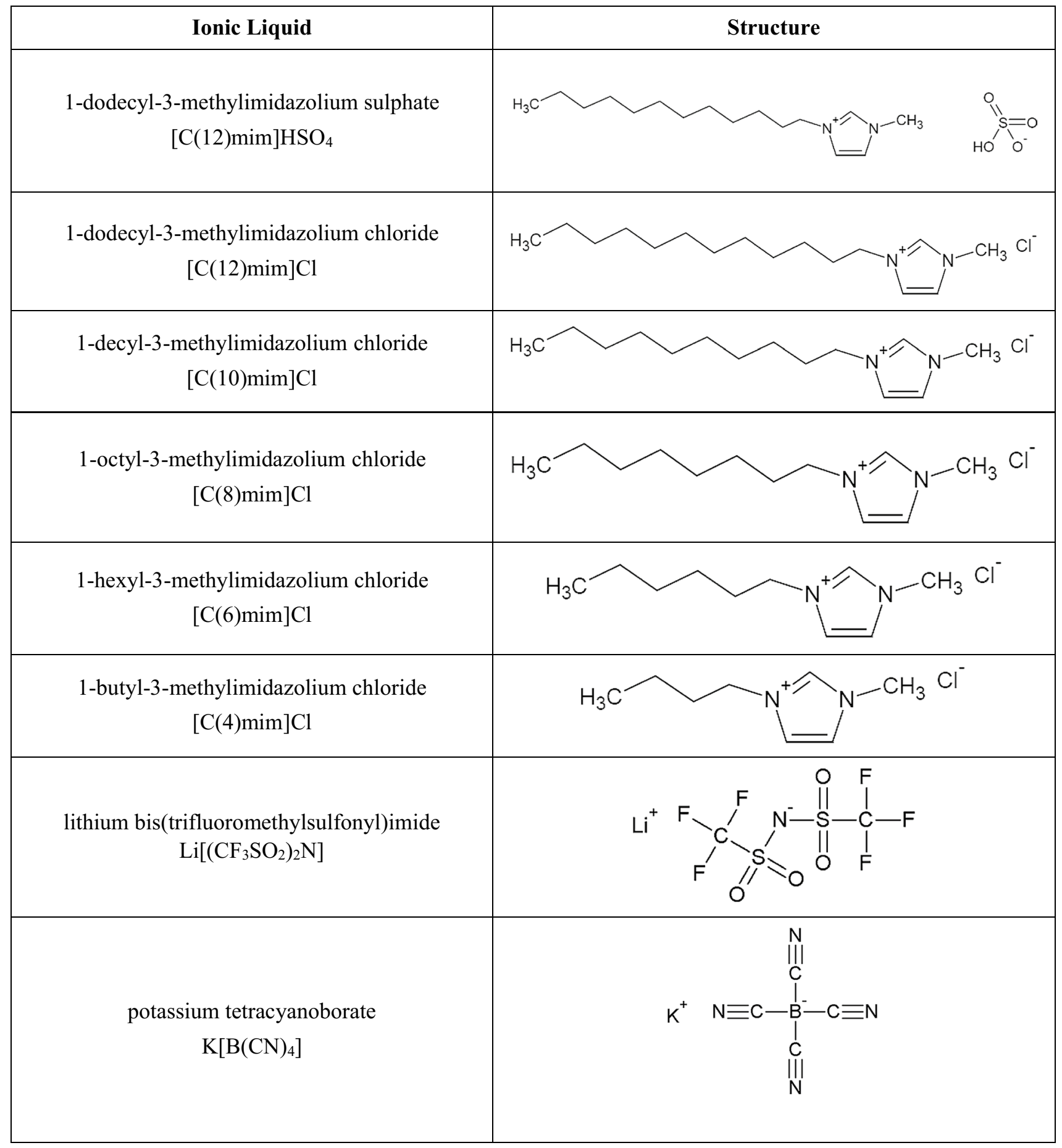

chromatographic column $-5 \mu \mathrm{m}, 4,6 \times 120 \mathrm{~mm}$, purchased from CS-Chromatographie Service GmbH (Germany) was used in the case of most of the analytes. The mobile phase was composed of acetonitrile (HPLC grade) and a buffer containing $20 \mathrm{mM} \mathrm{KH}_{2} \mathrm{PO}_{4}$ and $3.9 \mathrm{mM} \mathrm{H}_{3} \mathrm{PO}_{4}$. The proportions of acetonitrile and the buffer were as follows: $[\mathrm{C}(12)$ $\mathrm{mim}] \mathrm{HSO}_{4}$ and $[\mathrm{C}(12) \mathrm{mim}] \mathrm{Cl}: 50: 50(\mathrm{v} / \mathrm{v}),[\mathrm{C}(10) \mathrm{mim}] \mathrm{Cl}$ :
40:60 (v/v), [C(8)mim]Cl: 35:65 (v/v), [C(6)mim]Cl: 20:80 $(\mathrm{v} / \mathrm{v}),[\mathrm{C}(4) \mathrm{mim}] \mathrm{Cl}: 5: 95(\mathrm{v} / \mathrm{v})$. The analytical wavelength was $212 \mathrm{~nm}$. The flow rate was $1 \mathrm{ml} / \mathrm{min}$. The temperature was $30{ }^{\circ} \mathrm{C}$. The methods are characterized by very good linearity, confirmed by correlation coefficient values greater than 0.99 . The accuracy of the method was in an acceptable range from 90 to $120 \%$, and the values of coefficients of variation $(<3 \%$.) 
confirmed very good precision of the applied analytical methods. The limit of quantification (LOQ) was $5 \mu \mathrm{M}$, and the limit of detection (LOD) was $1.67 \mu \mathrm{M}$ in all cases.

The anions were analysed by employing a Metrohm 881 compact IC system (Metrohm, Herisau, Switzerland) with a conductometric detector. A Metrosep A Supp ion exchange column $(50 \times 4.0 \mathrm{~mm}$ ID and $5 \mu \mathrm{m}$ mean particle size $)$ coupled with a Metrosep A Supp 4/5 guard and a Metrosep RP guard was also exploited. The mobile phase was composed of acetonitrile and a buffer containing $3.2 \mathrm{mM} \mathrm{Na}_{2} \mathrm{CO}_{3}$ and $1 \mathrm{mM}$ $\mathrm{NaHCO}_{3}$. The proportions of acetonitrile and the buffer were as follows: $\left[\left(\mathrm{CF}_{3} \mathrm{SO}_{2}\right)_{2} \mathrm{~N}\right]^{-}: 30: 70(\mathrm{v} / \mathrm{v}),\left[\mathrm{B}(\mathrm{CN})_{4}\right]^{-}: 33: 67$ $(\mathrm{v} / \mathrm{v})$ (Stolte et al. 2011). The limit of quantification (LOQ) was $5 \mu \mathrm{M}$, and the limit of detection (LOD) was 1.67 in both cases.

\section{Modulation of non-specific binding in protein binding studies using the ultrafiltration method}

The separation of the analytes and the tested protein was carried out in ultrafiltration (UF) tubes with polyethersulfone (PES) membranes, with the molecular weight cut-off of $10 \mathrm{kDa}$. UF is a very simple and rapid method, but its major disadvantage is the non-specific binding (NSB) of compounds on filter membranes. When the studied compound binds widely to the filtration membrane, it may deviate from the true free concentration (Lee et al. 2003). Due to the strong possibility of NSB between imidazolium ionic liquids and the UF membrane, a method for NSB minimizing was tested. For this purpose, two substances: benzalkonium chloride (BAC) and polysorbate 20 (TW20) were used, because of their different properties-BAC is a cationic surfactant and TW20 is non-ionic surfactant. This allowed ascertaining which type of interaction between the ILs and the membrane is dominant and thus which of the surfactants will be more effective in NSB reduction. A detailed description of these methods is presented in the Supporting Information.

\section{Quantitative determination of non-specific binding}

In order to determine the non-specific binding (NSB) of ILs to filter membranes, $20 \mu \mathrm{L}$ of the respective IL at a concentration of $1000 \mu \mathrm{M}$, and $380 \mu \mathrm{L}$ of PBS were introduced into the upper compartment of the UF tube and then centrifuged (10 min, 16,000 g). The obtained filtrates were analysed by HPLC-DAD. At the same time, a solution of IL at a concentration of $50 \mu \mathrm{M}$ without centrifugation was analysed as a reference. NSB was calculated according to the following equation (Lee et al. 2003):

$\mathrm{NSB}=\left(\mathrm{C}_{\mathrm{BD}}-\mathrm{C}_{\mathrm{BF}}\right) / \mathrm{C}_{\mathrm{BD}}$
$\mathrm{C}_{\mathrm{BD}}$ represents the concentration of the IL solution in the reference sample, while $\mathrm{C}_{\mathrm{BF}}$ is the concentration of IL in the obtained filtrate after centrifugation.

\section{Determining the equilibrium time of IL partitioning to protein}

$380 \mu \mathrm{L}$ of HSA solution at a concentration of $0.1 \mathrm{mM}$ and $20 \mu \mathrm{L}$ of [IM1-12] $\mathrm{HSO}_{4}(c=1000 \mu \mathrm{M})$ were placed into seven Eppendorf tubes. The samples were subsequently incubated in a thermostated shaker $\left(37^{\circ} \mathrm{C}, 1000 \mathrm{rpm}\right)$ for 10, 20, 30, 40, 60, 100 and $120 \mathrm{~min}$. Afterwards, the samples were transferred to the upper compartments of ultrafiltration tubes (prepared according to procedure number 2) and centrifuged at $16,000 \mathrm{~g}$ for $15 \mathrm{~min}$. The obtained filtrates were analysed using HPLC-DAD.

\section{Critical micelle concentration}

\section{Conductometric measurements}

Conductometric measurements were carried out on the Cerko Lab System microtitration unit fitted with a $5-\mathrm{mL}$ Hamilton syringe and a CD-201 conductometric cell (HYDROMET). A weight calibration method was used for the syringe. The conductometric electrode was standardized with conductivity standards (aqueous $\mathrm{KCl}$ solutions) of conductivity, 84 and $200 \mu \mathrm{S} / \mathrm{cm}$ (Hamilton Company). The measurements were taken at $298.15 \pm 0.10 \mathrm{~K}$, controlled by a Lauda E100 circulation thermostat. The $1 \mathrm{mM}$ buffered solutions of the appropriate IL $(5 \mathrm{~mL})$ were conductometrically titrated with buffered IL solution $(35 \mathrm{mM})$. The titrant was added in $0.02-\mathrm{mL}$ increments and after a $45 \mathrm{~s}$ pause.

\section{Isothermal titration calorimetry}

All ITC experiments were performed at $298.15 \mathrm{~K}$ by exploiting an AutoITC isothermal titration calorimeter (MicroCal Inc. GE Healthcare, Northampton, the USA). Details of the measuring devices and experimental setup were described previously (Wyrzykowski et al. 2013). [C(10)mim]Cl and $[\mathrm{C}(12) \mathrm{mim}] \mathrm{Cl}$ were dissolved directly into the PBS buffer solution ( $\mathrm{pH}=7.4)$. The experiment consisted of injecting $10.02 \mu \mathrm{L}$ ( 29 injections, $2 \mu \mathrm{L}$ for the first injection only) of the buffered solution of IL at a concentration of $35 \mathrm{mM}$ into the reaction cell containing $1 \mathrm{mM}$ of the buffered solution of IL. All solutions were degassed prior to titration. The titrant was injected at 4 min intervals to ensure that the titration peak returned to the baseline before the next injection. Each injection lasted $20 \mathrm{~s}$. For homogeneous mixing in the cell, the stirrer speed was kept constant at $300 \mathrm{rpm}$. 


\section{Protein binding}

\section{Determining the percentage of ionic liquid bound to protein}

In order to quantitatively determine the cation and/or anion of the IL bound to protein (\% PB), $380 \mu \mathrm{L}$ of the HSA solution at a concentration of $0.1 \mathrm{mM}$ and $20 \mu \mathrm{L}$ of the respective ionic liquid solution at a concentration of $1000 \mu \mathrm{M}$ were added to Eppendorf tubes leading to a final concentration of $50 \mu \mathrm{M}$. Samples prepared in this way were incubated for $20 \mathrm{~min}$ at $37^{\circ} \mathrm{C}$ and $1000 \mathrm{rpm}$. Afterwards, the samples were transferred to UF tubes (prepared according to procedure 2) and centrifuged at $16,000 \mathrm{~g}$ for $15 \mathrm{~min}$. Simultaneously, the ultrafiltration process was also carried out for a solution containing $20 \mu \mathrm{L}$ of the ionic liquid at a concentration of $1000 \mu \mathrm{M}$ and $380 \mu \mathrm{L}$ of the PBS buffer in order to determine NSB and thereby confirm the efficiency of minimizing NSB by procedure 2 . The obtained filtrates and the reference IL solution at a concentration of $50 \mu \mathrm{M}$ (not filtrated using UF tubes) were analysed using HPLC-DAD. Additionally, the amount of the compound bound to protein for a nominal HSA concentration of $0.63 \mathrm{mM}(42 \mathrm{~g} / \mathrm{L})$ was assessed, due to the fact that this is the average physiological concentration of HSA in blood (Barnaby et al. 2011).

The percentage of ionic liquid bound to protein was calculated according to the equations presented below (Lee et al. 2003):

$f_{u}=C_{\mathrm{SF}} /(1-\mathrm{NSB}) / C_{\mathrm{SD}}$

$\% \mathrm{~PB}=100 \times\left(1-f_{u}\right)$

$f_{\mathrm{u}}$ : free fraction of IL; $C_{\mathrm{SF}}-\mathrm{IL}$ concentration in the filtrate; $C_{\mathrm{SD}}$ - IL concentration in the reference solution; NSBvalue of non-specific binding (determined in accordance with Eq. 1); \% PB—concentration of ionic liquid bound to protein.

\section{Evaluation of the influence of the anion on the affinity of the IL cation to protein}

To assess whether the concentration of the anion affects the affinity of the IL cation to protein, mixtures of [C(12)mim] $\mathrm{Cl}$ (constant concentration of $50 \mu \mathrm{M}$ ), and $\mathrm{K}\left[\mathrm{B}(\mathrm{CN})_{4}\right]$ at different concentrations $(1200,1000,800,500,80,20 \mu \mathrm{M})$ were tested. The concentration of HSA in this experiment was $0.1 \mathrm{mM}$. In parallel, a control sample containing only the PBS buffer, without protein, was investigated. The samples were incubated for $20 \mathrm{~min}$ at $37^{\circ} \mathrm{C}$ and $1000 \mathrm{rpm}$. Afterwards, both kinds of samples (the solution containing protein, as well as the reference sample (PBS without protein)) were transferred to ultrafiltration tubes and centrifuged for $15 \mathrm{~min}$ at $10,000 \mathrm{rpm}$. The obtained filtrates and the reference solution (not centrifuged using UF tubes) were analysed by HPLC-DAD and ion chromatography with conductometric detection in order to quantitatively determine both the cation and anion remaining in the water phase at the partitioning equilibrium.

\section{Isothermal titration calorimetry}

The thermodynamic parameters $(K, \Delta H)$ of the HSA interactions with the investigated anions, namely $\left[\mathrm{B}(\mathrm{CN})_{4}\right]^{-}$, $\left[\left(\mathrm{CF}_{3} \mathrm{SO}_{2}\right)_{2} \mathrm{~N}\right]^{-}$, and $\left[\left(\mathrm{C}_{2} \mathrm{~F}_{5}\right)_{3} \mathrm{PF}_{3}\right]^{-}$, were calculated based on the ITC data processed with Origin 7 from MicroCal. The experiments consisted of injecting $10.02 \mu \mathrm{L}$ (29 injections, $2 \mu \mathrm{L}$ for the first injection only) of $1 \mathrm{mM}$ (or $0.5 \mathrm{mM}$ ) buffered solution of an appropriate salt into a reaction cell that initially contained $0.05 \mathrm{mM}$ of a buffered solution of HSA. The titrant was injected at 5-min intervals. For each experiment, a blank was performed by injecting the titrant solution into a cell filled only with the buffer. This blank was subtracted from the corresponding titration to account for the heat of the dilution.

The enthalpy change $(\Delta H)$ of the HSA interactions with selected ILs $([\mathrm{C}(4) \mathrm{mim}] \mathrm{Cl},[\mathrm{C}(6) \mathrm{mim}] \mathrm{Cl},[\mathrm{C}(8) \mathrm{mim}] \mathrm{Cl}$, $[\mathrm{C}(10) \mathrm{mim}] \mathrm{Cl}$ and $[\mathrm{C}(7) \mathrm{mimCOOH}] \mathrm{Br}$ ) was measured according to the procedure described previously (Borowik et al. 2019). The titrant was HSA at a concentration of $0.1 \mathrm{mM}$, whereas in the reaction cell, the appropriate IL was at a concentration of $1-10 \mathrm{mM}([\mathrm{C}(4) \mathrm{mim}] \mathrm{Cl},[\mathrm{C}(6)$ $\mathrm{mim}] \mathrm{Cl}$, [[C(7)mimCOOH] Br, [C(10)mim] Cl: $5 \mathrm{mM},[\mathrm{C}(8)$ $\operatorname{mim}] \mathrm{Cl}: 10 \mathrm{mM},\left[\mathrm{C}(12) \mathrm{mim} \mathrm{HSO}_{4}: 1 \mathrm{mM}\right)$.

\section{Results and discussion}

\section{Determining the equilibrium time of IL partitioning to protein, NSB and CMC}

In the first stage of experiments (details shown in Supporting Information), the incubation time was investigated and set to $20 \mathrm{~min}$. In order to reduce NSB in the case of IL cations, procedure 2 (detailed description in Supporting Information) was chosen, in which the cationic surfactant benzalkonium chloride (BAC) was used. Through the application of this method, it was possible to reduce the value of NSB from approximately $90 \%$ to $41 \pm 2 \%$. In the case of the investigated IL anions, the membrane was pre-treated only with PBS. The ITC and conductometric titration measurements showed that the critical micelle concentration (CMC) values of $[\mathrm{C}(10) \mathrm{mim}] \mathrm{Cl}$ and $[\mathrm{C}(12) \mathrm{mim}] \mathrm{Cl}$ in a PBS buffer $(\mathrm{pH}=7.4)$ are significantly higher than the concentration of 
Table 2 Amount of IL binding to protein at concentrations of $0.63 \mathrm{mM}$

\begin{tabular}{ll}
\hline $\mathrm{IL}$ cation (with $\mathrm{Cl}^{-}$or $\mathrm{HSO}_{4}{ }^{-}$as counter ion) & $\% \mathrm{~PB}$ of cation \\
\hline$[\mathrm{C}(12) \mathrm{mim}]^{+}$ & $85 \pm 0.1$ \\
{$[\mathrm{C}(10) \mathrm{mim}]^{+}$} & $73 \pm 0.3$ \\
{$[\mathrm{C}(8) \mathrm{mim}]^{+}$} & $17 \pm 4$ \\
{$[\mathrm{C}(6) \mathrm{mim}]^{+}$} & $5 \pm 1$ \\
{$[\mathrm{C}(4) \mathrm{mim}]^{+}$} & $\mathrm{nb}$ \\
\hline
\end{tabular}

$n b$ no binding observed

ILs used in the study of partitioning to protein, so micelles could not be formed under the experimental conditions.

\section{Protein binding}

\section{Determining the percentage of ionic liquid bound to protein}

For all cations, the albumin concentration was at $0.63 \mathrm{mM}$. This mimics physiological conditions. In the case of selected cations: $[\mathrm{C}(12) \mathrm{mim}]^{+},[\mathrm{C}(6) \mathrm{mim}]^{+}$and $[\mathrm{C}(4) \mathrm{mim}]^{+}$, experiments were also carried out with HSA at concentrations of $0.1 \mathrm{mM}$ in order to ascertain whether HSA concentration may affect the $\mathrm{PB}$.

The results presented in Table 2 show that $[\mathrm{C}(12) \mathrm{mim}]^{+}$ and $[\mathrm{C}(10) \mathrm{mim}]^{+}$exhibited the highest affinity to HSA. The $\%$ PB values are definitely lower for the other cations: [C(8) $\mathrm{mim}]^{+}$and $[\mathrm{C}(6) \mathrm{mim}]^{+}$. Furthermore, in the case of $[\mathrm{C}(4)$ $\mathrm{mim}]^{+}$, no significant binding could be determined. The obtained results indicate that the binding of ionic liquids to HSA strongly depends on the structure of the cation and increases with the length of the hydrocarbon chain (Table 2).

A similar trend was observed by Huang et al. who showed that the binding strength of $[\mathrm{C}(4) \mathrm{mim}] \mathrm{Cl},[\mathrm{C}(6) \mathrm{mim}] \mathrm{Cl}$ and [C(8)mim] $\mathrm{Cl}$ to bovine serum albumin (BSA) is dependent on the length of the carbon chain (Huang et al. 2013). According to Zhong et al. the binding affinity between PFAS and HSA is also closely related to the hydrophobicity, and their bioaccumulation ability increases with an increase in perfluoroalkyl carbon chain length (Zhong et al. 2019). Moreover, Henneberger et al. demonstrated that the additional $-\mathrm{CH}_{2}$ group in the structure of various ionic compounds brings about an increase in the logarithmic value of the partition coefficient between BSA and water $\left(\log K_{\mathrm{BSA} / \mathrm{w}}\right)$ from 0.28 to 0.62 (Henneberger et al. 2016). However, this average range relates mainly to anions, as only four cations were investigated in this study.

For cations, Henneberger et al. obtained very weak binding, though a high concentration of albumin was used $(50 \mathrm{~g} / \mathrm{L})$. In contrast, a stronger binding of long-chain imidazolium cations on albumin was reported by Zhang et al.
2018 (Zhang et al. 2018). This work tallies well with our findings. In addition, Zhang et al. by using molecular modelling, have indicated enhanced binding of imidazolium ILs with the increase of the number of carbon atoms of the hydrophobic chain. Still, at the same time, electrostatic interaction of the imidazolium ring with the positive charge of selected amino acids cannot be excluded (Zhang et al. 2018).

Although more studies regarding the influence of ILs on HSA have been presented in the literature, they focus mainly on the denaturation effect of ILs on protein and do not quantitatively evaluate the degree of binding of ILs to this protein (Page et al. 2009; McCarty et al. 2008; Kumar et al. 2012; Sasmal et al. 2011; Chowdhury et al. 2012; Heller et al. 2013; Akdogan et al. 2011a, b; Baker et al. 2009; Rawat et al. 2012). The available literature data in unison, however, confirm that ILs may destabilize the secondary structure of albumin, and the concentration that initiates this process decreases with the increasing hydrophobicity of the compound (Page et al. 2009; McCarty et al. 2008; Kumar et al. 2012; Sasmal et al. 2011; Chowdhury et al. 2012; Heller et al. 2013; Akdogan et al. 2011a, b; Baker et al. 2009; Rawat et al. 2012).

The probable reason for this phenomenon is the increasing contact surface area of the cation due to the increasing length of the alkyl chain (Silva et al. 2014). The concentration that may cause the destabilization of albumin equals 35,2 and $0.2 \%(\mathrm{w} / \mathrm{v})$ for $[\mathrm{C}(2) \mathrm{mim}]^{+},[\mathrm{C}(4) \mathrm{mim}]^{+}$and $[\mathrm{C}(8) \mathrm{mim}]^{+}$, respectively (Rawat et al. 2012; Akdogan et al. 2011b; Page et al. 2009). Therefore, on the basis of the available literature data, we could assume that it was unlikely that the protein structure was destabilized during this experiment, since the used concentration of $50 \mu \mathrm{M}$ corresponded to a concentration not exceeding $0.002 \%$ (w/v), depending on the molar mass of the respective IL. Moreover, for long-chain imidazolium ILs, e.g. 1-tetradecyl-3-methylimidazoliumbromide ([C(14)mim]Br), previous research has demonstrated that at concentration below CMC, [C(14)mim]Br, barely affects the secondary structure of bovine serum albumin (BSA), whereas a destabilizing effect is observed above concentrations corresponding to CMC (Yan et al. 2012; Geng et al. 2010).

Table 3 PB values of ILs anions and different HSA concentrations

\begin{tabular}{lll}
\hline $\begin{array}{l}\mathrm{IL} \text { anion with } \mathrm{Li}^{+} \text {or } \mathrm{K}^{+} \text {as } \\
\text { counter ion }\end{array}$ & $\begin{array}{l}\text { Albumin concentra- } \\
\text { tions }(\mathrm{mM})\end{array}$ & \% PB of anion \\
\hline$\left[\left(\mathrm{CF}_{3} \mathrm{SO}_{2}\right)_{2} \mathrm{~N}\right]^{-}$ & 0.1 & $93 \pm 2$ \\
{$\left[\left(\mathrm{CF}_{3} \mathrm{SO}_{2}\right)_{2} \mathrm{~N}\right]^{-}$} & 0.01 & 36 \\
{$\left[\mathrm{~B}(\mathrm{CN})_{4}\right]^{-}$} & 0.1 & $75 \pm 11$ \\
{$\left[\mathrm{~B}(\mathrm{CN})_{4}\right]^{-}$} & 0.01 & $14 \pm 3$ \\
\hline
\end{tabular}


The results of the assessment of the affinity of different anions of ILs to albumin (at two concentrations) are summarized in Table 3.

At the albumin concentration of $0.1 \mathrm{mM}$, the anion $\left[\left(\mathrm{CF}_{3} \mathrm{SO}_{2}\right)_{2} \mathrm{~N}\right]^{-}$has a higher affinity to protein than the analysed cations (Table 2). Furthermore, the $\mathrm{PB}$ of $\left[\mathrm{B}(\mathrm{CN})_{4}\right]^{-}$is slightly lower $(75 \%)$ than the PB value determined for $[\mathrm{C}(12)$ $\mathrm{mim}]^{+}(85 \%)$. In the case of anions, albumin concentration has an impact on their protein binding. Higher \% PB values were determined for the anion $\left[\left(\mathrm{CF}_{3} \mathrm{SO}_{2}\right)_{2} \mathrm{~N}\right]^{-}$. However, in the case of both anions, the value of $\%$ PB decreases significantly with the decrease in albumin concentration (Table 3), which indicates that the protein undergoes saturation by the analysed ligand at this condition.

The available literature data on the affinity of organic bases to albumin show that benzoic, naphthoic and phenoxy acids strongly bind to this protein $(>90 \%)$ (Henneberger et al. 2016). In this work, the value obtained for $\left[\left(\mathrm{CF}_{3} \mathrm{SO}_{2}\right)_{2} \mathrm{~N}\right]^{-}(93 \%)$ is similar to the PB of PFAS, for which high binding to BSA (>95\%) was observed. Based on the aforementioned literature and the values of $\% \mathrm{~PB}$ for $\mathrm{Li}\left[\left(\mathrm{CF}_{3} \mathrm{SO}_{2}\right)_{2}\right]$ and $\mathrm{K}\left[\mathrm{B}(\mathrm{CN})_{4}\right]$ that we obtained, it can be assumed that the hydrophobic anions of ILs can strongly interact with HSA. This effect may affect transport and distribution processes in living organisms.

All the dependencies described above concerning the degree of binding of ILs with HSA result from its binding properties and its multidomain structure. This comprises three homologous domains (I, II, III), each of which is divided into two subdomains (A and B) (Artali et al. 2005). The binding mostly occurs at two well-known drug-binding sites, i.e. Sudlow's site I-which locates at subdomain IIA of HSA, and Sudlow's site II-found at the subdomain IIIA. However, other binding sites with similar function exist (Artali et al. 2005).

The fatty acids binding sites have some significance with regard to this effect, as HSA is able to bind seven equivalents of fatty acids (FAs). Currently, the binding sites in HSA for ILs are unknown. However, compounds of similar structure are mechanistically better understood. It has been shown that perfluorooctanylsulfonyl acid (PFOS) shows affinity for two binding sites of the HSA. The first is located at Sudlow site II, and the second is at the FA6 binding site. In addition, previous studies have revealed that the strongly polar sulfonyl group of PFOS may bind to hydrophilic residues of HSA, while the fluorinated carbon chain interacts with adjacent hydrophobic protein residues (Luo et al. 2012).

The literature indicates that biomolecule stability at very low IL concentrations $(<0.01 \mathrm{M})$ is predominantly driven by electrostatic interactions (Jha et al. 2018). However, our study, which including a relatively broad spectrum of imidazolium cations, clearly revealed the higher affinity of longchain ILs to HSA, and hence, their binding at even lower IL concentration might be related also to interaction with the hydrophobic domains (IIA and IIIA) of HSA. The fact that ILs interact with the protein through both electrostatic and hydrophobic interactions has been confirmed by other studies (Zhang et al. 2018; Geng et al. 2009, 2010; Mester et al. 2010; Pei et al. 2012; Yan et al. 2012; Cao et al. 2014; Wang et al. 2012; Zhu et al. 2011; Singh et al. 2012; Bharmoria et al. 2014).

Additionally, many authors have observed that the process of the binding of imidazolium ILs to protein is mostly hydrophobic in nature and mainly controlled through the alkyl chains of cations (Huang et al. 2013; Geng et al. 2009; Yan et al. 2012; Cao et al. 2014; Wang et al. 2012; Singh et al. 2012). Nevertheless, it has been demonstrated that the secondary structure of albumin is destabilized with the increasing concentration of ILs, and that this effect is brought about by the hydrophobic interaction of the IL with the protein and can lead to denaturation (Geng et al. 2009).

That we conclude the existence of a high affinity of anions (in comparison to cations) to HSA is justified because protein generally prefers binding to small, negatively charged hydrophobic molecules (He et al. 1992). Moreover, the obtained results may be attributed to the chaotropicity of the studied anions, leading to a great affinity towards chaotropic amide in the structure of the protein (Harada et al. 2018).

\section{Evaluation of the influence of anions on the affinity of cations of ionic liquids to protein}

As it has been recently shown, the membrane-water partition coefficient $\left(\log \mathrm{K}_{\mathrm{MW}}\right)$ of the cation is altered by the concentration of anions $\left[\mathrm{B}(\mathrm{CN})_{4}\right]^{-}$and $\left[\left(\mathrm{FSO}_{2}\right)_{2} \mathrm{~N}\right]^{-}$indicating stronger partitioning of $[\mathrm{C}(12) \mathrm{mim}]^{+}$probably due to ion pairing, reduction of repulsive interaction with choline by anion adsorption on bilayer surfaces, neutralization of the charge of choline and/or changes of lipid bilayer integrity (Dołżonek et al. 2017). Furthermore, according to the study by Figueiredo et al. (2013) organic anions are less hydrated compared to simple inorganic anions, and thus, their availability to interact with proteins could be higher. The ionic strength of the solution is also not negligible for interactions with proteins. At low ionic strength, the anion may have a greater tendency to associate with the cation, which in turn increases their tendency to dehydrate the protein surface. This may translate into a higher affinity of the anion for the protein (Figueiredo et al. 2013).

Therefore, we aimed to ascertain whether the affinity of the cation $[\mathrm{C}(12) \mathrm{mim}]^{+}$to HSA depends on the concentration of the tetracyanoborate anion $\left[\mathrm{B}(\mathrm{CN})_{4}\right]^{-}$. In this experiment, cation $[\mathrm{C}(12) \mathrm{mim}]^{+}$at concentration of $50 \mu \mathrm{M}$ was used with the addition of various concentrations of the tetracyanoborate anion added as $\mathrm{K}\left[\mathrm{B}(\mathrm{CN})_{4}\right]^{-}$. Apart from the quantitative determination of the cation, the obtained 
Fig. 1 The graph showing the $\% \mathrm{~PB}$ for $[\mathrm{C}(12) \mathrm{mim}]^{+}(50 \mu \mathrm{M})$ in the presence of different concentrations of $\left[\mathrm{B}(\mathrm{CN})_{4}\right]^{-}$and $\%$ $\mathrm{PB}$ for different concentrations of $\left[\mathrm{B}(\mathrm{CN})_{4}\right]^{-}$in the presence of $[\mathrm{C}(12) \mathrm{mim}]^{+}(50 \mu \mathrm{M})$

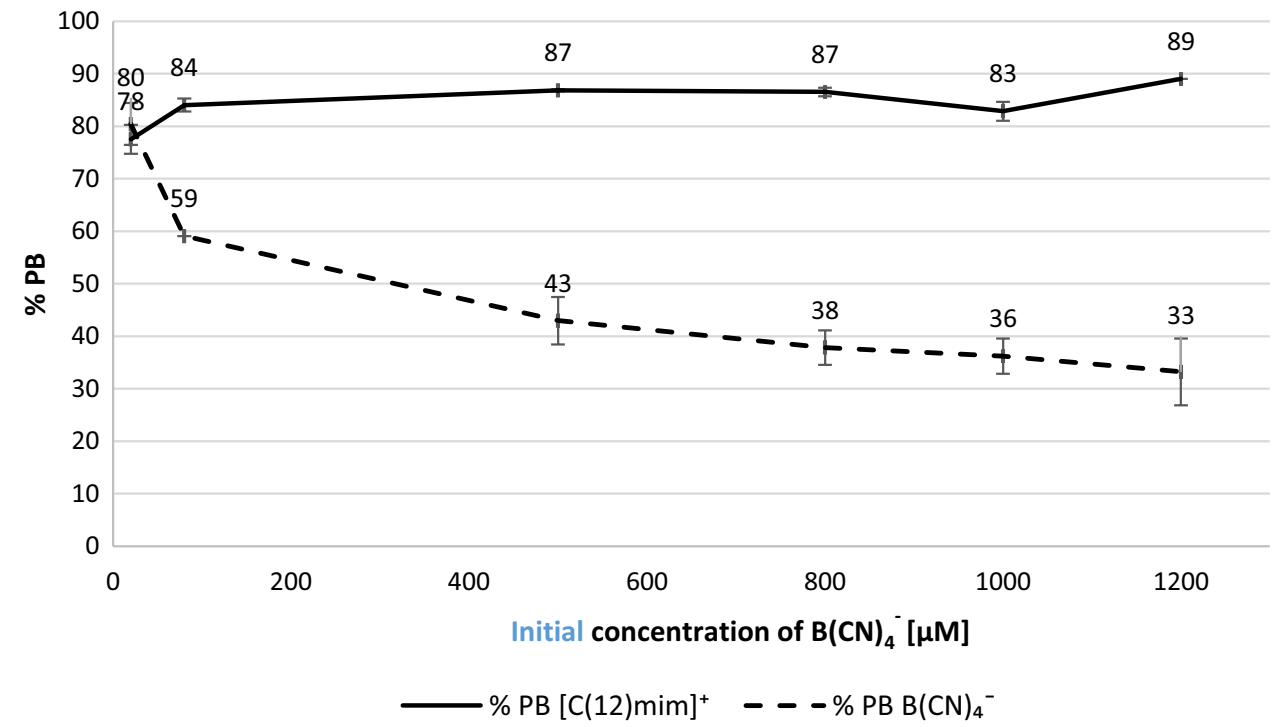

samples were subjected to additional analyses in order to determine the concentration of the anion remaining in the water phase after the experiment. The $\% \mathrm{~PB}$ of the anion $\left[\mathrm{B}(\mathrm{CN})_{4}\right]^{-}$is presented in Fig. 1.

The obtained results clearly show that the anion $\left[\mathrm{B}(\mathrm{CN})_{4}\right]^{-}$binds to HSA. Therein, the values of $\% \mathrm{~PB}$ for $\left[\mathrm{B}(\mathrm{CN})_{4}\right]^{-}$decrease along with an increase in the initial concentration of the anion; thus, the gradual saturation of the protein with the studied anion as its concentration increases has been observed (Fig. 1). Additionally, while the concentration of the anion $\left[\mathrm{B}(\mathrm{CN})_{4}\right]^{-}$bound to HSA increases, the amount of the cation $[\mathrm{C}(12) \mathrm{mim}]^{+}$bound to albumin is also slightly higher. This may give an indication that the affinity of the IL cation to albumin was enhanced by the previously bound anion. Thus, the probable formation of ion-pairs between $[\mathrm{C}(12) \mathrm{mim}]^{+}$and $\left[\mathrm{B}(\mathrm{CN})_{4}\right]^{-}$may result from the nature of both ions, likely to be chaotropic.

Although the interpretation of Hofmeister effects at the molecular level is difficult to elucidate, especially for ions more complex than simple inorganic ions (Harada et al. 2018; Constantinescu et al. 2010), some studies have tried to assign a chaotropic/kosmotropic character to selected IL cations and anions. Schröder (2017) suggested that imidazolium cations act more and more chaotropic when the alkyl side chains are prolonged (Schröder 2017). Other studies also indicate the chaotropic behaviour of imidazolium cations (Akdogan et al. 2011a; Reslan et al. 2018).

Unfortunately, so far the chaotropicity of $\left[\mathrm{B}(\mathrm{CN})_{4}\right]^{-}$has not yet been studied, but taking into consideration that this anion is fairly hydrophobic and hence does not form a hydrogen bond with water molecules (is weakly hydrated), it can be considered as a 'structure-breaker', meaning a chaotrope (Tariq et al. 2011; Patel et al. 2014). This tallies with other studies indicating that cyanamide anions act as chaotropes (Schröder 2017; Mester et al. 2015). The strongest interaction between cations and anions exists if both are chaotropic (Schröder 2017). Hence, ion pairing between the investigated cation and anion could be possible and might explain the enhanced $[\mathrm{C}(12) \mathrm{mim}]^{+}$binding to HSA in the presence of $\left[\mathrm{B}(\mathrm{CN})_{4}\right]^{-}$. However, the observed increase in cation binding is too little (from 78 to $89 \%$ ) to consider ion pairing as mechanistic interpretation of protein binding for IL cations and anions. Moreover, increase of [C(12)mim $]^{+}$ binding was lower than we expected, as it was not directly proportional to $\mathrm{PB}$ of $\left[\mathrm{B}(\mathrm{CN})_{4}\right]^{-}$.

Unlike other experiments, the concentration of the anion was in this experiment much higher (up to $1.2 \mathrm{mM}$ ). Therefore, in this case, we need to consider the possible destabilizing effect upon HSA that is induced by moving the positively charged amino acid towards the anion. This could start the unfolding process and might make the repulsion to the cation stronger (Schröder 2017). Hence, it may diminish ion pairing at a high concentration of $\left[\mathrm{B}(\mathrm{CN})_{4}\right]^{-}$, resulting in weaker binding of $[\mathrm{C}(12) \mathrm{mim}]^{+}$than suspected.

\section{Determination of the enthalpy value $(\Delta H)$ of HSA-IL interactions}

The conditional parameters of the HSA interactions with $\mathrm{K}\left[\mathrm{B}(\mathrm{CN})_{4}\right], \mathrm{Li}\left[\left(\mathrm{CF}_{3} \mathrm{SO}_{2}\right)_{2} \mathrm{~N}\right], \mathrm{K}\left[\left(\mathrm{C}_{2} \mathrm{~F}_{5}\right)_{3} \mathrm{PF}_{3}\right],[\mathrm{C}(8) \mathrm{mim}]$ $\left[\mathrm{B}(\mathrm{CN})_{4}\right]$ and $\left[\mathrm{C}(12) \mathrm{mim}^{2} \mathrm{HSO}_{4}\right.$ were obtained directly from the ITC data by fitting binding isotherms, using nonlinear least-squares procedures, to a model that assumes a single set of identical binding sites. The representative binding isotherm for the $[\mathrm{C}(12) \mathrm{mim}] \mathrm{HSO}_{4}-(\mathrm{HSA})$ interaction is shown in Fig. 2, whereas conditional parameters $\left(K_{\text {ITC }}, \Delta H\right)$ of the interactions under study are summarized in Table 4. 


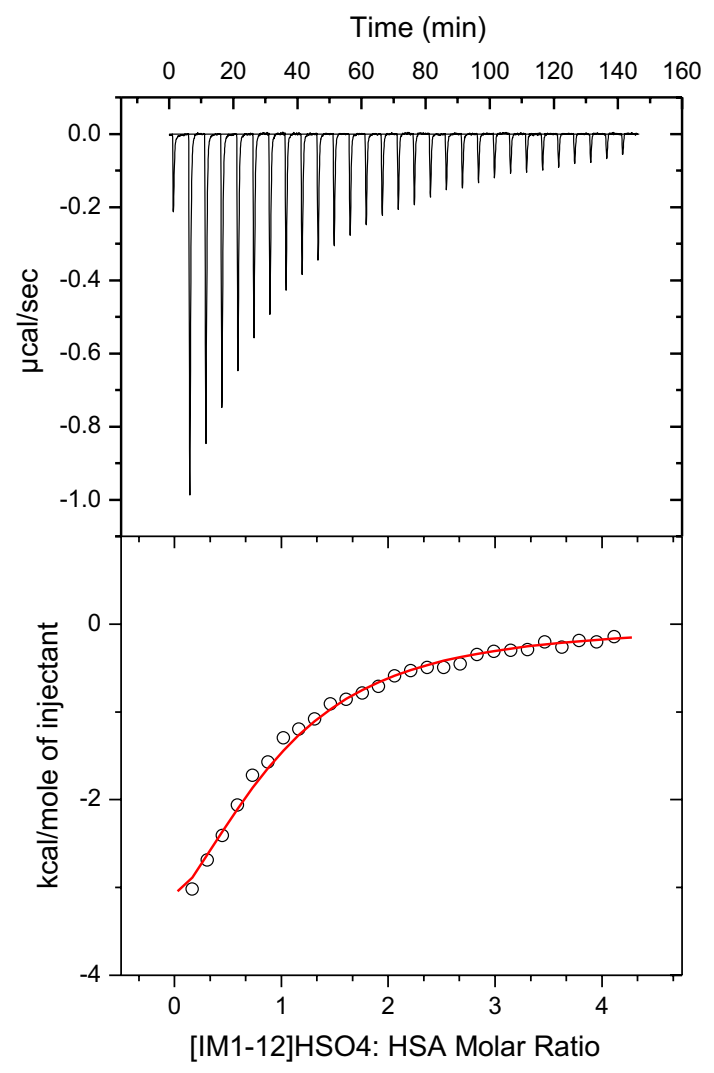

Fig. 2 Calorimetric titration isotherm of the binding interaction between $\left[\mathrm{C}(12) \mathrm{mim}^{2} \mathrm{HSO}_{4}(1 \mathrm{mM})\right.$ and HSA $(0.05 \mathrm{mM})$ in PBS buffer of a $\mathrm{pH}$ of 7.4 , at $298.15 \mathrm{~K}$

Table 4 The condition-dependent thermodynamic data $\left(K_{\mathrm{ITC}}, \Delta H_{\mathrm{ITC}}\right)$ of ILs binding to HSA in PBS buffer of $\mathrm{pH} 7.4$, at $298.15 \mathrm{~K}$, obtained by ITC ( \pm Standard Deviation Values)

\begin{tabular}{llll}
\hline No & Ionic liquid & $\Delta H_{\text {ITC }}(\mathrm{kcal} / \mathrm{mol})$ & $\log K_{\mathrm{a}}$ \\
\hline 1 & $\mathrm{~K}\left[\mathrm{~B}(\mathrm{CN})_{4}\right]$ & $-16.67 \pm 0.82$ & $3.79 \pm 0.03$ \\
2 & $\mathrm{Li}\left[\left(\mathrm{CF}_{3} \mathrm{SO}_{2}\right)_{2} \mathrm{~N}\right]$ & $-12.7 \pm 3.57$ & $4.26 \pm 0.1$ \\
3 & $\mathrm{~K}\left[\left(\mathrm{C}_{2} \mathrm{~F}_{5}\right)_{3} \mathrm{PF}_{3}\right]$ & $-12.90 \pm 0.74$ & $4.32 \pm 0.06$ \\
4 & {$[\mathrm{C}(8) \mathrm{mim}]\left[\mathrm{B}(\mathrm{CN})_{4}\right]$} & $-17.36 \pm 0.86$ & $3.78 \pm 0.03$ \\
5 & {$[\mathrm{C}(12) \mathrm{mim}] \mathrm{HSO}_{4}$} & $-5.25 \pm 0.11$ & $4.51 \pm 0.03$ \\
\hline
\end{tabular}

Due to the weaker interactions of HSA with the IL cations comprising the alkyl chain length lower than 12 ([C(4) $\mathrm{mim}]^{+},[\mathrm{C}(6) \mathrm{mim}]^{+},[\mathrm{C}(8) \mathrm{mim}]^{+},[\mathrm{C}(10) \mathrm{mim}]^{+}$, and $[\mathrm{C}(7)$ mimCOOH$\left.]^{+}\right)$, only binding enthalpies $(\Delta H)$ could be calculated indirectly (Woziwodzka et al. 2013). Thus, three types of experiments were carried out: (1) titration of ILs with the buffer, (2) titration of the buffer with HSA and (3) titration of ILs with HSA. The enthalpy change $(\Delta H)$ of the HSA-IL interaction was calculated by the linear regression of experimental points (the differences between the heat of titrations of ILs with HSA and the sum of the heat of ILs
Table 5 The condition-dependent binding enthalpies $\left(\Delta H_{\text {ITC }}\right)$ of IL interactions with HSA in a PBS buffer of $\mathrm{pH} 7.4$, at $298.15 \mathrm{~K}$, obtained by ITC ( \pm Standard deviation values)

\begin{tabular}{llr}
\hline No & Ionic liquid & $\Delta H_{\text {ITC }}(\mathrm{kcal} / \mathrm{mol})$ \\
\hline 1 & {$[\mathrm{C}(4) \mathrm{mim}] \mathrm{Cl}$} & $4.95 \pm 0.08$ \\
2 & {$[\mathrm{C}(6) \mathrm{mim}] \mathrm{Cl}$} & $6.63 \pm 0.11$ \\
3 & {$[\mathrm{C}(8) \mathrm{mim}] \mathrm{Cl}$} & $10.18 \pm 0.12$ \\
4 & {$[\mathrm{C}(10) \mathrm{mim}] \mathrm{Cl}$} & $12.62 \pm 0.18$ \\
5 & {$[\mathrm{C}(7) \mathrm{mimCOOH}] \mathrm{Br}$} & $-23.93 \pm 0.22$ \\
\hline
\end{tabular}

with the buffer and of the buffer with HSA titrations) to the infinite dilution of HSA ([HSA] $\rightarrow 0$ ) (Table 5 ).

The heat of HSA-IL interactions (corrected for background thermal effects) is calculated as $\mathrm{kcal} \mathrm{mol}^{-1}$ of the injected HSA. On the basis of the literature data (Jungnickel et al. 2008; Sadeghi et al. 2015; Wang et al. 2011; Liu et al. 2013) and our results of investigations of CMC in the PBS buffer, we can assume that ITC measurements were performed for monomers of ILs. The stability of the resulting complexes is governed by the type of anion and is enhanced with the increase of its size and the hydrophobicity in the following direction (Table 4):

$\left[\mathrm{B}(\mathrm{CN})_{4}\right]^{-}<\left[\left(\mathrm{C}_{2} \mathrm{~F}_{5}\right)_{3} \mathrm{PF}_{3}\right]^{-}=\left[\left(\mathrm{CF}_{3} \mathrm{SO}_{2}\right)_{2} \mathrm{~N}\right]^{-}$

This finding is in line with the results obtained from the ultrafiltration method (Table 3). The formations of ILsHSA complexes are exothermic processes (Table 4). Thus, it can be concluded that polar interactions as well as hydrogen bonds play an important role in the stabilization of the investigating complexes.

On the other hand, in the endothermic effects of $[\mathrm{C}(4)$ $\mathrm{mim}]^{+},[\mathrm{C}(6) \mathrm{mim}]^{+},[\mathrm{C}(8) \mathrm{mim}]^{+}$and $[\mathrm{C}(10) \mathrm{mim}]^{+}$, binding to HSA is observed (Table 5). According to the literature, this may be attributed to low degrees of saturation of HSA being related to relatively low concentrations (Juni et al. 1983) and indicates that imidazolium cations bind to HSA via ionic and hydrophobic interactions (Ross et al. 1981). Nevertheless, the delocalization of the positive charge onto the large imidazolium ring may induce weaker electrostatic interactions between HSA and imidazolium cations (Liu et al. 2013). In such a case, the formation of the complexes is an entropy-driven process. Furthermore, there is a strong dependency between the binding enthalpy and the alkyl chain length (Table 5). Herein, the binding enthalpy increases with the increase of the length of the alkyl chain presented in the structure of the cation.

A different situation is seen for $[\mathrm{C}(12) \mathrm{mim}] \mathrm{HSO}_{4}$ which in contradiction to other investigated IL cations and interacts exothermically with HSA. The resulting [C(12)mim] $\mathrm{HSO}_{4}(\mathrm{HSA})$ complex is as stable as complexes of HSA with 
the IL anions under study (Table 4). The exothermic effect of the $[\mathrm{C}(12) \mathrm{mim}]^{+}$cation interaction with milk protein has previously been observed by Liu et al. (2013). In their work, the negative value in the binding enthalpy change was attributed to the significant contribution of hydrogen bonding in the binding of $[\mathrm{C}(12) \mathrm{mim}]^{+}$to protein. The hydrophobic association of protein by ILs is known to contribute to a positive value of enthalpy change (Ross et al. 1981), while the formation of new non-covalent bonding, such as electrostatic (Coulombic) attraction, van der Waals interactions or hydrogen bonds, is exothermic in nature (Abraham et al. 2005).

These findings tally with the enthalpy changes measured for $[\mathrm{C}(7) \mathrm{mimCOOH}] \mathrm{Br}$. The $[\mathrm{C}(7) \mathrm{mimCOOH}]^{+}$cation is undoubtedly able to form an interaction with HSA via hydrogen bonding, and the heat of this interaction could be measured as exothermic (Table 5). Although our results do not confirm these types of interaction between imidazolium cations and HSA, they cannot be excluded, and a positive contribution to the overall enthalpy change may arise from the thermodynamically unfavourable release of ordered water molecules from protein (Abraham et al. 2005).

It is worth noticing that the binding constants of the $[\mathrm{C}(8)$ $\operatorname{mim}]\left[\mathrm{B}(\mathrm{CN})_{4}\right] /(\mathrm{HSA})$ and $\mathrm{K}\left[\mathrm{B}(\mathrm{CN})_{4}\right] /(\mathrm{HSA})$ complexes are equal in the range of the experimental error. This suggests that the affinity of the IL anions towards HSA is higher than the IL cations comprising alkyl chain lengths lower than 12 .

These results also show the utmost importance of focussing on both the cation and anion of ILs separately (as inorganic salts) when the assessment of the interaction with biomolecules, e.g. proteins, in an aqueous solution is conducted by methods like ITC or by other techniques that are not based on the quantitation of the free fraction of the cation and/or anion in the water phase, but on the other effects of protein binding (e.g. the energetic effect). Such an approach allows a proper estimation because it provides information on which ion is responsible for the measured end-point, being a reflection of the interaction with the biomolecule.

\section{Conclusions}

In this study, the binding of IL cations and anions to HSA was quantitatively evaluated in order to preliminarily assess the role of exemplary blood protein in their potential bioconcentration. Data obtained by using UF method revealed that both the cations and anions of ILs may bind to HSA, and hence, blood proteins may play an important role in the bioconcentration of ILs. The binding of ILs to HSA depends on the hydrophobicity (alkyl chain length) and structure (e.g. polar moieties) of cations and increases as the length of the alkyl chain of the cation increases (from $5 \pm 1 \%$ for $[\mathrm{C}(6) \mathrm{mim}]^{+}$to $85 \pm 0.1 \%$ for $\left.[\mathrm{C}(12) \mathrm{mim}]^{+}\right)$, whereas polar functional groups weaken the binding and the binding mechanism might be driven by other types of interactions (e.g. hydrogen bonding).

In contrast to previous studies indicating Coulombic forces as the main interaction responsible for the binding of imidazolium cations at low concentrations, and hydrophobic interactions for higher concentrations, our results show that hydrophobicity may be an important factor underlying the partitioning of imidazolium ILs to HSA, also at relatively very low concentrations (below $50 \mu \mathrm{M}$ ), which, however, does not exclude the role of electrostatic interactions.

Our results indicate that the type of anion has an influence on the affinity of the cation to HSA. This dependence is essential from the environmental point of view, where the chemicals do not exist as individual compounds but as a mixture. For this reason, future studies of the bioaccumulation of ionic or ionogenic compounds should consider the influence of interactions between all the ionic components of a matrix.

Due to the fact that the presented study is one of the first that focuses on the assessment of the quantitative binding of ILs to protein, future complementary studies are needed.

Supplementary Information The online version contains supplementary material available at https://doi.org/10.1007/s11696-021-02021-y.

Author contributions DK and JD were involved in conceptualization, investigation, writing - original draft; PS contributed to supervision; SS was involved in conceptualization, writing-review and editing; DW contributed to investigation, writing—original draft.

Funding The authors would like to acknowledge the financial support of the Institutional Strategy of the University of Bremen, funded by the German Excellence Initiative, the Deutsche Forschungsgemeinschaft (DFG), German Research Foundation, Project Number 380298548) and the National Science Centre (Poland) Under Decision NCN2016/23/G/ ST5/04245.

Data availability All data generated or analysed during this study are included in this published article [and its supplementary information files].

\section{Declarations}

Conflict of interest The authors declare that they have no competing interests.

Open Access This article is licensed under a Creative Commons Attribution 4.0 International License, which permits use, sharing, adaptation, distribution and reproduction in any medium or format, as long as you give appropriate credit to the original author(s) and the source, provide a link to the Creative Commons licence, and indicate if changes were made. The images or other third party material in this article are included in the article's Creative Commons licence, unless indicated otherwise in a credit line to the material. If material is not included in the article's Creative Commons licence and your intended use is not permitted by statutory regulation or exceeds the permitted use, you will need to obtain permission directly from the copyright holder. To view a copy of this licence, visit http://creativecommons.org/licenses/by/4.0/. 


\section{References}

Abraham T, Lewis RN, Hodges RS, McElhaney RN (2005) Isothermal titration calorimetry studies of the binding of a rationally designed analogue of the antimicrobial peptide gramicidin s to phospholipid bilayer membranes. Biochemistry 44(6):2103-2112

Akdogan Y, Hinderberger D (2011) Solvent-induced protein refolding at low temperatures. J Phys Chem B 115(51):15422-15429

Akdogan Y, Junk MJ, Hinderberger D (2011) Effect of ionic liquids on the solution structure of human serum albumin. Biomacromol 12(4):1072-1079

Armitage JM, Erickson RJ, Luckenbach T, Ng CA, Prosser RS, Arnot JA, Nichols JW (2017) Assessing the bioaccumulation potential of ionizable organic compounds: current knowledge and research priorities. Environ Toxicol Chem 36(4):882-897

Artali R, Bombieri G, Calabi L, Del Pra A (2005) A molecular dynamics study of human serum albumin binding sites. Il Farmaco 60(6-7):485-495

Baker GA, Heller WT (2009) Small-angle neutron scattering studies of model protein denaturation in aqueous solutions of the ionic liquid 1-butyl-3-methylimidazolium chloride. Chem Eng J 147(1):6-12

Barnaby OS, Cerny RL, Clarke W, Hage DS (2011) Comparison of modification sites formed on human serum albumin at various stages of glycation. Clin Chim Acta 412(3-4):277-285

Bharmoria P, Rao KS, Trivedi TJ, Kumar A (2014) Biamphiphilic ionic liquid induced folding alterations in the structure of bovine serum albumin in aqueous medium. J Phys Chem B 118(1):115-124

Borowik A, Butowska K, Konkel K, Banasiuk R, Derewonko N, Wyrzykowski D, Piosik J (2019) Theimpact of surface functionalization on the biophysical properties of silver nanoparticles. Nanomaterials 9(7):973

Cao C, Lei J, Huang T, Du FP (2014) Impact of ionic liquid-type imidazolium surfactant addition on dynamic properties of BSA adsorption layers at different $\mathrm{pH}$. Soft Matter 10(44):8896-8904

Chowdhury R, Mojumdar SS, Chattoraj S, Bhattacharyya K (2012) Effect of ionic liquid on the native and denatured state of a protein covalently attached to a probe: solvation dynamics study. J Chem Phys 137(5):055104

Constantinescu D, Herrmann C, Weingärtner H (2010) Protein denaturation by ionic liquids and the Hofmeister series. In: Ionic liquids: from knowledge to application; Plechkova, N., et al.; ACS Symposium Series; American Chemical Society: Washington, DC

Cornellas A, Perez L, Comelles F, Ribosa I, Manresa A, Garcia MT (2011) Self-aggregation and antimicrobial activity of imidazolium and pyridinium based ionic liquids in aqueous solution. J Colloid Interface Sci 355(1):164-171

Dołżonek J, Cho CW, Stepnowski P, Markiewicz M, Thöming J, Stolte S (2017) Membrane partitioning of ionic liquid cations, anions and ion pairs: estimating the bioconcentration potential of organic ions. Environ Pollut 228:378-389

Dong B, Zhao X, Zheng L, Zhang J, Li N, Inoue T (2008) Aggregation behavior of long-chain imidazolium ionic liquids in aqueous solution: micellization and characterization of micelle microenvironment. Colloids Surf A Physicochem Eng Aspects 317(13):666-672

Endo S, Escher BI, Goss KU (2011) Capacities of membrane lipids to accumulate neutral organic chemicals. Environ Sci Technol 45(14):5912-5921

Fanali G, Di Masi A, Trezza V, Marino M, Fasano M, Ascenzi P (2012) Human serum albumin: from bench to bedside. Mol Aspects Med 33(3):209-290

Figueiredo AM, Sardinha J, Moore GR, Cabrita EJ (2013) Protein destabilisation in ionic liquids: the role of preferential interactions in denaturation. Phys Chem Chem Phys 15(45):19632-19643
Franco A, Ferranti A, Davidsen C, Trapp S (2010) An unexpected challenge: ionizable compounds in the REACH chemical space. Int J Life Cycle Assess 15(4):321-325

Geisler A, Endo S, Goss KU (2012) Partitioning of organic chemicals to storage lipids: elucidating the dependence on fatty acid composition and temperature. Environ Sci Technol 46(17):9519-9524

Geng F, Zheng L, Liu J, Yu L, Tung C (2009) Interactions between a surface active imidazolium ionic liquid and BSA. Colloid Polym Sci 287(11):1253

Geng F, Zheng L, Yu L, Li G, Tung C (2010) Interaction of bovine serum albumin and long-chain imidazolium ionic liquid measured by fluorescence spectra and surface tension. Process Biochem 45(3):306-311

Gramatica P, Cassani S, Sangion A (2015) PBT assessment and prioritization by PBT index and consensus modeling: comparison of screening results from structural models. Environ Int 77:25-34

Harada LK, Pereira JF, Campos WF, Silva EC, Moutinho CG, Vila MM, Tubino M (2018) Insights into protein-ionic liquid interactions aiming at macromolecule delivery systems. J Braz Chem Soc 29(10): 1983-1998

He XM, Carter DC (1992) Atomic structure and chemistry of human serum albumin. Nature 358(6383):209-215

Heller WT (2013) Comparison of the thermal denaturing of human serum albumin in the presence of guanidine hydrochloride and 1-butyl-3-methylimidazolium ionic liquids. The J Phys Chem B 117(8):2378-2383

Henneberger L, Goss KU, Endo S (2016) Equilibrium sorption of structurally diverse organic ions to bovine serum albumin. Environ Sci Technol 50(10):5119-5126

Huang R, Zhang S, Pan L, Li J, Liu F, Liu H (2013) Spectroscopic studies on the interactions between imidazolium chloride ionic liquids and bovine serum albumin. Spectrochim Acta A Mol Biomol Spectrosc 104:377-382

Jeremias G, Jesus F, Ventura SP, Gonçalves FJ, Asselman J, Pereira JL (2021) New insights on the effects of ionic liquid structural changes at the gene expression level: molecular mechanisms of toxicity in Daphnia magna. J Hazard Mater 409:124517

Jha I, Bisht M, Mogha NK, Venkatesu P (2018) Effect of imidazolium-based ionic liquids on the structure and stability of stem bromelain: concentration and alkyl chain length effect. J Phys Chem B 122(30):7522-7529

Jiao J, Zhang Y, Fang L, Yu L, Sun L, Wang R, Cheng N (2013) Electrolyte effect on the aggregation behavior of 1-butyl-3-methylimidazolium dodecylsulfate in aqueous solution. J Colloid Interface Sci 402:139-145

Jungnickel C, Łuczak J, Ranke J, Fernández JF, Müller A, Thöming J (2008) Micelle formation of imidazolium ionic liquids in aqueous solution. Colloids Surf A Physicochem Eng 316(1-3):278-284

Juni K, Nieves EA, Perrin JH (1983) Some novel observations of a drug (indoprofen) - albumin interaction. Biopharm Drug Dispos 4(1):1-7

Khan MI, Mubashir M, Zaini D, Mahnashi MH, Alyami BA, Alqarni AO, Show PL (2021) Cumulative impact assessment of hazardous ionic liquids towards aquatic species using risk assessment methods. J Hazard Mater 415:125364

Klamt A, Huniar U, Spycher S, Keldenich J (2008) COSMOmic: a mechanistic approach to the calculation of membrane- water partition coefficients and internal distributions within membranes and micelles. J Phys Chem B 112(38):12148-12157

Kowalska D, Maculewicz J, Stepnowski P, Dołżonek J (2021) Ionic liquids as environmental hazards-Crucial data in view of future PBT and PMT assessment. J Hazard Mater 403:123896

Kumar Das D, Kumar Das A, Kumar Mandal A, Mondal T, Bhattacharyya K (2012) Effect of an ionic liquid on the unfolding of human serum albumin: a fluorescence correlation spectroscopy study. Chem Phys Chem 13(7):1949-1955 
Lee KJ, Mower R, Hollenbeck T, Castelo J, Johnson N, Gordon P, Lee YH (2003) Modulation of nonspecific binding in ultrafiltration protein binding studies. Pharm Res 20(7):1015-1021

Liu Y, Yang L, Guo R (2013) Interaction between $\beta$-casein micelles and imidazolium-based ionic liquid surfactant. Soft Matter 9(13):3671-3680

Lu Y, Meng L, Ma D, Cao H, Liang Y, Liu H, Jiang G (2021) The occurrence of PFAS in human placenta and their binding abilities to human serum albumin and organic anion transporter 4. Environ Pollut 273:116460

Łuczak J, Hupka J, Thöming J, Jungnickel C (2008) Self-organization of imidazolium ionic liquids in aqueous solution. Colloids Surf A Physicochem Eng 329(3):125-133

Luo Z, Shi X, Hu Q, Zhao B, Huang M (2012) Structural evidence of perfluorooctane sulfonate transport by human serum albumin. Chem Res Toxicol 25(5):990-992

Mackay D (1982) Correlation of bioconcentration factors. Environ Sci Technol 16(5):274-278

McCarty TA, Page PM, Baker GA, Bright FV (2008) Behavior of acrylodan-labeled human serum albumin dissolved in ionic liquids. Ind Eng Chem 47(3):560-569

Mena IF, Diaz E, Palomar J, Rodriguez JJ, Mohedano AF (2020) Cation and anion effect on the biodegradability and toxicity of imidazolium-and choline-based ionic liquids. Chemosphere 240:124947

Mester P, Wagner M, Rossmanith P (2010) Biased spectroscopic protein quantification in the presence of ionic liquids. Anal Bioanal Chem 397(5): 1763-1766

Mester P, Wagner M, Rossmanith P (2015) Antimicrobial effects of short chained imidazolium-based ionic liquids-Influence of anion chaotropicity. Ecotoxicol Environ Saf 111:96-101

Meylan WM, Howard PH, Boethling RS (1996) Improved method for estimating water solubility from octanol/water partition coefficient. Environ Toxicol Chem 15(2):100-106

Nendza M, Kühne R, Lombardo A, Strempel S, Schüürmann G (2018) PBT assessment under REACH: Screening for low aquatic bioaccumulation with QSAR classifications based on physicochemical properties to replace BCF in vivo testing on fish. Sci Total Environ 616:97-106

Ng CA, Hungerbühler K (2013) Bioconcentration of perfluorinated alkyl acids: how important is specific binding? Environ Sci Technol 47(13):7214-7223

Nowicki J, Łuczak J, Stańczyk D (2016) Dual functionality of amphiphilic 1-alkyl-3-methylimidazolium hydrogen sulfate ionic liquids: surfactants with catalytic function. RSC Adv 6(14):11591-11601

Page TA, Kraut ND, Page PM, Baker GA, Bright FV (2009) Dynamics of loop 1 of domain $I$ in human serum albumin when dissolved in ionic liquids. J Phys Chem B 113(38):12825-12830

Patel R, Kumari M, Khan AB (2014) Recent advances in the applications of ionic liquids in protein stability and activity: a review. Appl Biochem Biotechnol 172(8):3701-3720

Pei Y, Li Z, Liu L, Wang J (2012) Partitioning behavior of amino acids in aqueous two-phase systems formed by imidazolium ionic liquid and dipotassium hydrogen phosphate. J Chromatogr A $1231: 2-7$

Rawat K, Bohidar HB (2012) Universal charge quenching and stability of proteins in 1-methyl-3-alkyl (hexyl/octyl) imidazolium chloride ionic liquid solutions. J Phys Chem B 116(36):11065-11074

REACH (2006) Regulation (EC) No. 1907/2006 of the European Parliament and of the Council of 18 December 2006 concerning the Registration, Evaluation, Authorisation and Restriction of Chemicals (REACH). Available from: https://eur-lex.europa.eu/
legal-content/EN/TXT/PDF/?uri=CELEX:02006R1907-20140 410\&from $=$ EN Accessed 2020 March 20

Reslan M, Kayser V (2018) Ionic liquids as biocompatible stabilizers of proteins. Biophys Rev 10(3):781-793

Ross PD, Subramanian S (1981) Thermodynamics of protein association reactions: forces contributing to stability. Biochemistry 20(11):3096-3102

Sadeghi R, Golabiazar R (2015) Surface and micellar properties of ionic liquid 1-dodecyl-3-methylimidazolium bromide in aqueous solution in the absence and presence of a series of organic electrolytes. J Chem Eng Data 60(4):1063-1071

Samorì C, Pasteris A, Galletti P, Tagliavini E (2007) Acute toxicity of oxygenated and nonoxygenated imidazolium-based ionic liquids to Daphnia magna and Vibrio fischeri. Environ Toxicol Chem 26(11):2379-2382

Sasmal DK, Mondal T, Sen Mojumdar S, Choudhury A, Banerjee R, Bhattacharyya K (2011) An FCS study of unfolding and refolding of CPM-labeled human serum albumin: role of ionic liquid. J Phys Chem B 115(44):13075-13083

Schröder C (2017) Proteins in ionic liquids: current status of experiments and simulations. In: Ionic liquids II (pp. 127-152). Springer, Cham

Silva M, Figueiredo AM, Cabrita EJ (2014) Epitope mapping of imidazolium cations in ionic liquid-protein interactions unveils the balance between hydrophobicity and electrostatics towards protein destabilisation. Phys Chem Chem Phys 16(42):23394-23403

Singh T, Bharmoria P, Morikawa MA, Kimizuka N, Kumar A (2012) Ionic liquids induced structural changes of bovine serum albumin in aqueous media: a detailed physicochemical and spectroscopic study. J Phys Chem B 116(39):11924-11935

Steudte S, Stepnowski P, Cho CW, Thöming J, Stolte S (2012) (Eco) toxicity of fluoro-organic and cyano-based ionic liquid anions. Chem Commun 48(75):9382-9384

Steudte S, Bemowsky S, Mahrova M, Bottin-Weber U, Tojo-Suarez E, Stepnowski P, Stolte S (2014) Toxicity and biodegradability of dicationic ionic liquids. RSC Adv 4(10):5198-5205

Stolte S, Abdulkarim S, Arning J, Blomeyer-Nienstedt AK, BottinWeber U, Matzke M, Thöming J (2008) Primary biodegradation of ionic liquid cations, identification of degradation products of 1-methyl-3-octylimidazolium chloride and electrochemical wastewater treatment of poorly biodegradable compounds. Green Chem 10(2):214-224

Stolte S, Steudte S, Markowska A, Arning J, Neumann J, Stepnowski P (2011) Ion chromatographic determination of structurally varied ionic liquid cations and anions - a reliable analytical methodology applicable totechnical and natural matrices. Anal Methods 3(4):919-926

Tariq M, Carvalho PJ, Coutinho JA, Marrucho IM, Lopes JNC, Rebelo LP (2011) Viscosity of (C2-C14) 1-alkyl-3-methylimidazolium bis (trifluoromethylsulfonyl) amide ionic liquids in an extended temperature range. Fluid Ph Equilibria 301(1):22-32

Wang J, Zhang L, Wang H, Wu C (2011) Aggregation behavior modulation of 1-dodecyl-3-methylimidazolium bromide by organic solvents in aqueous solution. J Phys Chem B 115(17):4955-4962

Wang X, Liu J, Sun L, Yu L, Jiao J, Wang R (2012) Interaction of bovine serum albumin with ester-functionalized anionic surface-active ionic liquids in aqueous solution: a detailed physicochemical and conformational study. J Phys Chem B 116(41):12479-12488

Woziwodzka A, Gołuński G, Wyrzykowski D, Kaźmierkiewicz R, Piosik J (2013) Caffeine and other methylxanthines as interceptors of food-borne aromatic mutagens: inhibition of 
Trp-P-1 and Trp-P-2 mutagenic activity. Chem Res Toxicol 26(11):1660-1673

Wyrzykowski D, Pilarski B, Jacewicz D, Chmurzyński L (2013) Investigation of metal-buffer interactions using isothermal titration calorimetry. J Therm Anal Calorim 111(3):1829-1836

Yan H, Wu J, Dai G, Zhong A, Chen H, Yang J, Han D (2012) Interaction mechanisms of ionic liquids [Cnmim] $\mathrm{Br}(\mathrm{n}=4,6,8,10)$ with bovine serum albumin. J Lumin 132(3):622-628

Ye Z, Zetterberg C, Gao H (2017) Automation of plasma protein binding assay using rapid equilibrium dialysis device and Tecan workstation. J Pharmaceut Biomed 140:210-214

Yue W, Mo L, Zhang J (2021) Reproductive toxicities of 1-ethyl3-methylimidazolium bromide on Caenorhabditis elegans with oscillation between inhibition and stimulation over generations. Sci Total Environ 765:144334

Zhang M, Wang Y, Zhang H, Cao J, Fei Z, Wang Y (2018) Impact of the alkyl chain length on binding of imidazolium-based ionic liquids to bovine serum albumin. Spectrochim Acta A Mol Biomol Spectrose 196:323-333

Zhong W, Zhang L, Cui Y, Chen M, Zhu L (2019) Probing mechanisms for bioaccumulation of perfluoroalkyl acids in carp (Cyprinus carpio): impacts of protein binding affinities and elimination pathways. Sci Total Environ 647:992-999

Zhu LY, Li GQ, Zheng FY (2011) Interaction of bovine serum albumi with two alkylimidazolium-based ionic liquids investigated by microcalorimetry and circular dichroism. J Biophys Chem 2(02): 147

Publisher's Note Springer Nature remains neutral with regard to jurisdictional claims in published maps and institutional affiliations. 